\title{
The Sensitizers Nickel Sulfate and 2,4-dinitrofluorobenzene Increase CD40 and IL-12 Receptor Expression in a Fetal Skin Dendritic Cell Line
}

\author{
Ana Luísa Vital, ${ }^{1,2}$ Margarida Gonçalo, ${ }^{3,4}$ Maria Teresa Cruz, ${ }^{1,2}$ Américo Figueiredo, ${ }^{3}$ \\ Carlos B. Duarte, ${ }^{2}$ and Maria Celeste Lopes ${ }^{1,2}$
}

\begin{abstract}
Dendritic cells (DCs) are antigen-presenting cells (APCs) capable of capturing haptens and to process and present them to $\mathrm{T}$ lymphocytes. In order to sensitize $\mathrm{T}$ cells for contact hypersensitivity (CHS), skin DCs suffer a maturation process with modifications on their surface molecules. The aim of this work was to evaluate changes induced by two contact sensitizers, 2,4-dinitrofluorobenzene (DNFB) and nickel sulfate $\left(\mathrm{NiSO}_{4}\right)$, and a non-sensitizer 2,4-dichloronitrobenzene (DCNB), on the protein levels of two activation markers, CD40 and IL-12 receptor (IL-12R), in a mouse skin dendritic cell line (FSDC). The expression of CD40 and IL-12R proteins was evaluated by western blot assay and direct immunofluorescence microscopy. The results showed that CD40 and IL-12R expression increased significantly after cell exposure to $\mathrm{NiSO}_{4}$ and DNFB, although DNFB exhibited a stronger activity. There was no effect with DCNB. The epidermal cytokine granulocytemacrophage colony-stimulating factor (GM-CSF), also used in the experiments, slightly increased the expression of both CD40 and IL-12R and when tested together with the sensitizers the effect was partially additive. The results suggest that the sensitizers DNFB and $\mathrm{NiSO}_{4}$ are directly involved on the changes of the surface markers CD40 and IL-12R in skin DCs, during the sensitization phase of CHS, and this effect may be enhanced by GMCSF. In contrast, no effect was observed with DCNB.
\end{abstract}

KEY WORDS: Dendritic cells; CD40; IL-12 receptor; GM-CSF; skin sensitizers; Nickel; DNFB; DCNB.

\section{INTRODUCTION}

Contact hypersensitivity (CHS) is a common inflammatory skin disease that occurs as a consequence of increasing exposure to exogenous chemicals. It is a dendritic cell-dependent, T cell-derived and cytokine-mediated skin inflammation (Enk, 1997;

\footnotetext{
${ }^{1}$ Faculdade de Farmácia, Universidade de Coimbra, Rua do Norte, 3000-295, Coimbra, Portugal.

${ }^{2}$ Centro de Neurociências e Biologia Celular, Universidade de Coimbra, 3004-517, Coimbra, Portugal.

${ }^{3}$ Faculdade de Medicina (Serviço de Dermatologia), Hospital da Universidade de Coimbra, 3000-075, Coimbra, Portugal.

${ }^{4}$ To whom all correspondence should be addressed. Margarida Gonçalo, Faculdade de Medicina (Serviço de Dermatologia), Hospital da Universidade de Coimbra, 3000-075, Coimbra, Portugal. Fax: + 351-239480217, E-mail: mmgoncalo@netcabo.pt.
} 
Watanabe et al., 2002). Langerhans cells (LCs) and keratinocytes are epidermal cells that produce, constitutively or upon exogenous stimulation, a wide range of cytokines (Kimber et al., 1995). These cytokines interact with appropriate receptors expressed by LCs becoming crucial in the sensitization phase and in initiation of the CHS (Watanabe et al., 2002).

LCs and other skin dendritic cells (DCs) are antigen presenting cells (APCs) that play an important role in determining the cutaneous response to small chemicals applied at the skin surface (Enk, 1997; Watanabe et al., 2002). These cells capture the small molecular weight exogenous chemical (the hapten) by phagocytosis or by pynocytosis, process it into a small hapten-modified peptide and combine this allergen with a MHC molecule (Lipscomb and Masten, 2002). At this stage skin DCs are very efficient in the uptake and processing of the antigens but poor stimulators of primary $\mathrm{T}$ cell responses and, in the skin they would not find naïve $\mathrm{T}$ cells for priming. Therefore, they undergo maturation to become potent APCs and migrate to the skin draining lymph nodes searching the appropriate naïve $\mathrm{T}$ cells for sensitization (Girolomoni et al., 1995; Pieri et al., 2001; Satthaporn and Eremin, 2001).

The migration and maturation process of skin DCs involves profound changes on the molecules that are expressed at their cell surface (Banchereau and Steinman, 1998), namely MHC class II (Herouet et al., 2000) and costimulatory molecules (Coutant KD et al., 1999; Tuschl and Kovac, 2001), and on those secreted to the extracellular milieu, including cytokines (Pichowski et al., 2000; De Smedt et al., 2001) and metalloproteinases (Ratzinger et al., 2002).

In vitro studies, using whole human skin models, cultures of DCs derived from circulating CD34 + cells or immortalized animal skin dendritic cells (Girolomoni et al., 1995; Herouet et al., 2000; Tuschl et al 2000; De Smedt et al., 2001), have shown a direct effect of some sensitizing chemicals, namely nickel, chromium, 2,4-dinitrochlorobenzene (DNCB), 2,4-dinitrofluorobenzene (DNFB) and 2,4,6-trinitrobenzene sulfonic acid (TNBS), on the phenotypic and functional characteristics of DCs. They upregulate DC expression of MHC class II and costimulatory molecules, namely CD54, CD86, CD40, CD83 (Coutant et al., 1999; Herouet et al., 2000; De Smedt et al., 2001; Tuschl and Kovac, 2001). Some reports indicate that sensitizing chemicals may increase IL-1 $\beta$ and IL-12 secretion by DC cells although this is still a matter of debate, since these responses were not always observed (Coutant et al., 1999; Aiba et al., 2000; Pichowski et al., 2000; De Smedt et al., 2001; Tuschl and Kovac, 2001).

In this work, using a mouse fetal skin dendritic cell line (FSDC), we studied the changes in the expression of membrane-associated receptors induced by chemicals with different skin sensitizing properties, alone or in the presence of GM-CSF. GM$\mathrm{CSF}$ is one of the epidermal cytokines produced by keratinocytes after epidermal application of skin sensitizers, being responsible for DC maturation (Kimber et al., 1995; Pieri et al., 2001). The present work showed that nickel sulfate $\left(\mathrm{NiSO}_{4}\right)$, the most prevalent allergen in the human population, and DNFB, a potent experimental sensitizer, upregulated DC expression of the CD40 protein and of the IL-12 receptor (IL-12R). In contrast 2,4-dichloronitrobenzene (DCNB), an analogous of DNFB which is considered a non-sensitizer (Becker et al., 1994), did not exhibit these effects. The epidermal cytokine GM-CSF, which induces the maturation of FSDC (Kimber et al., 1995; Jonuleit et al., 1996), also slightly increased CD40 and IL-12R expression, and this effect was additive with the response to the sensitizers. 


\section{MATERIALS AND METHODS}

\section{Materials}

DNFB was purchased from Sigma-Aldrich Química (Madrid, Spain). DCNB and $\mathrm{NiSO}_{4}$ were from Sigma Chemical Co (St. Louis, MO, USA). The mouse recombinant GM-CSF was from R \& D systems (Minneapolis, MN, USA). The rabbit anti-mouse CD40 immunoglobulin and the rabbit anti-human antibody to IL-12 receptor beta 1 subunit (IL-12R $\beta 1$ ) were obtained from Santa Cruz Biotechnology (Santa Cruz, CA). The mouse monoclonal antibody against actin and the protease inhibitor cocktail were from Roche (Carnaxide, Portugal). Fetal calf serum was from Biochrom KG (Berlin, Germany) and trypsin from Invitrogen (Paisley, UK). The fluorescein isothiocyanate (FITC)-conjugated swine anti-rabbit immunoglobulin and the swine serum were from DAKO (Copenhagen, Denmark). The mounting medium for fluorescence, Vectashield, was obtained from Vector Laboratories, Inc. (Burlingame, CA, U.S.A.). The ECL western blotting analysis system, the horseradish peroxidase-conjugated donkey anti-rabbit immunoglobulin and the $\mathrm{X}$-ray films were from Amersham Biosciences (Carnaxide, Portugal). The horseradish peroxidaseconjugated goat anti-mouse immunoglobulin was from Pierce (Illinois, USA). Triton ${ }^{\circledR}$ X 100 and paraformaldehyde were from Merck (Lisboa, Portugal). All other reagents were from Sigma Chemical Co (St. Louis, MO, USA).

\section{Cell culture}

The fetal mouse skin dendritic cell line FSDC, kindly supplied by Dr. G. Girolomoni (Laboratory of Immunology, Instituto Dermopatico dell'Imacolata, IRCCS, Rome, Italy), is a skin dendritic cell precursor with antigen presenting capacity (Girolomoni et al., 1995). The cells were cultured in endotoxin free Iscove's Modified Dulbecco's Medium (IMDM), supplemented with 10\% (v/v) fetal calf serum, $1 \%(\mathrm{w} / \mathrm{v})$ glutamine, $3.02 \mathrm{~g} / 1$ sodium bicarbonate, $100 \mu \mathrm{g} / \mathrm{ml}$ streptomycin and $100 \mathrm{U} / \mathrm{ml}$ penicillin. For western blot analysis, FSDC were plated at $2 \times 10^{6}$ cells/well, in six-well culture plates, whereas for immunofluorescence analysis, FSDC cells were grown on a Lab-Tek chamber slide with cover $\left(0.2 \times 10^{6}\right.$ cells/slide $)$.

The effect of DNFB and $\mathrm{NiSO}_{4}$ on the expression of CD40 and IL-12R in FSDC was determined by western blot and immunocytochemistry, after incubating the cells with the compounds for $24 \mathrm{hr}$. The concentrations of DNFB $(1 \mu \mathrm{g} / \mathrm{ml})$ and $\mathrm{NiSO}_{4}(50 \mu \mathrm{g} / \mathrm{ml})$ used were those that produced maximal effect and no toxicity (data not shown), as evaluated by the reduction of the tetrazolium bromide salt, 3-(4,5-dimethylthiazol-2-yl)-2,5-diphenyl tetrazolium bromide (MTT) (Mosmann, 1983).

$\mathrm{NiSO}_{4}$ was dissolved in culture medium. DNFB and DCNB were dissolved in DMSO in a stock solution $(10 \mathrm{mg} / \mathrm{ml})$. Before incubation of the cells with these compounds (DNFB and DCNB) the stock solution was diluted in sterile PBS $(10 \times)$ and the final concentrations of DNFB and DCNB were further diluted in the culture medium containing the FSDC cells $(1000 \times)$. Therefore, the concentration of DMSO incubated with cells never exceeded $0.01 \%$. Under these experimental conditions the assay of cellular MTT reduction (a viability assay) in the presence of this concentration of DMSO revealed no toxic effect and this concentration of 
DMSO alone was without effect on CD40 and IL-12R expression (data not shown).

\section{Western blot analysis}

Total cell lysates were obtained after harvesting the cells in a sonication buffer containing $0.32 \mathrm{M}$ sucrose, $10 \mathrm{mM}$ Tris- $\mathrm{HCl}(\mathrm{pH}$ 7.5), $1 \mathrm{mM}$ ethylene-diaminetetraacetic acid, $1 \mathrm{mM}$ dithiothreitol, $0.1 \mathrm{mM}$ phenylmethylsulfonylfluoride and the protease inhibitor cocktail. Then, the lysates were incubated on ice for $30 \mathrm{~min}$ and sonicated to disrupt the cells. Protein concentration was determined using the bicinchoninic acid method.

In brief, protein samples were denatured and separated on a $10 \%(\mathrm{v} / \mathrm{v})$ SDSPAGE, and transferred to a PVDF membrane. The membrane was blocked with 5\% $(\mathrm{w} / \mathrm{v})$ dry milk in Tris-buffered saline with $0.1 \%(\mathrm{v} / \mathrm{v})$ Tween 20 , for $1 \mathrm{hr}$. The levels of CD40 and IL-12R $\beta 1$ proteins were detected using a rabbit anti-mouse CD40 (1:500) and a rabbit anti-human IL-12R $\beta 1$ (1:500) antibody, for $1 \mathrm{hr}$, followed by incubation with a horseradish peroxidase-conjugated donkey anti-rabbit antibody (1:5000). The immunocomplexes were visualized by the ECL chemiluminescence method. To demonstrate equivalent protein loading the membranes were stripped and reprobed with an anti-actin antibody (1:10000), followed by incubation with a horseradish peroxidase-conjugated goat anti-mouse immunoglobulin (1:25000).

\section{Immunofluorescence microscopy (immunocytochemistry)}

After incubation in the absence or in the presence of the appropriate stimuli, as indicated in Figs. 2c and 3c, the cells were washed with PBS and fixed with PBS containing $4 \%(\mathrm{w} / \mathrm{v})$ sucrose and $4 \%(\mathrm{w} / \mathrm{v})$ paraformaldehyde, for $15 \mathrm{~min}$. FSDC were then permeabilized in PBS containing $1 \%(\mathrm{v} / \mathrm{v})$ Triton ${ }^{\circledR}$ X 100 , for $10 \mathrm{~min}$. Non-specific binding was blocked by incubation of the cells with PBS supplemented with normal swine serum $(1: 20)$ and $0.5 \%$ (w/v) BSA-PBS, for $45 \mathrm{~min}$, at room temperature. Cells were then incubated with a rabbit anti-mouse CD40 immunoglobulin (1:50) or with a rabbit anti-human IL-12R $\beta 1$ antibody (1:50), for $90 \mathrm{~min}$ at room temperature. After rinsing with PBS, the cells were incubated with FITC-conjugated swine anti-rabbit immunoglobulin (1:40) in $0.5 \%$ BSA-PBS, for $45 \mathrm{~min}$. The cells were rinsed again and mounted with the mounting medium for fluorescence, Vectashield. Cells labeled with FITC-anti CD40 or with FITC-anti IL-12R $\beta 1$ antibodies were photographed on a Zeiss Axiovert 200 microscope. Control experiments consisted of processing the same preparations as described, except for the omission of the primary antibody, and resulted in no specific staining.

\section{Data analysis}

Results are presented as mean \pm SEM of the indicated number of experiments. Mean values were compared using one-way ANOVA and the Bonferroni's multiple comparison test. The significance level was $* p<0.05,{ }^{*} * p<0.01$ and $* * * p<0.001$. 


\section{RESULTS}

\section{Effect of $\mathrm{NiSO}_{4}$, DNFB and DCNB on CD40 expression in FSDC}

Stimulation of the cells with $\mathrm{NiSO}_{4}(50 \mu \mathrm{g} / \mathrm{ml})$ or DNFB $(1 \mu \mathrm{g} / \mathrm{ml})$, for $24 \mathrm{hr}$, increased significantly the expression of CD40, by 32 and $50 \%$, respectively (Fig. 1a, lanes 3 and 4) as demonstrated by western blot. In order to determine how FSDC maturation affects the expression of CD40 induced by sensitizers, the cells were preincubated with GM-CSF (100ng/ml), for $24 \mathrm{hr}$, before stimulation with $\mathrm{NiSO}_{4}$ or DNFB. GM-CSF was previously shown to induce the differentiation and maturation of DCs progenitors (Kimber et al., 1995; Jonuleit et al., 1996; Banchereau and Steinman, 1998) and, in particular, of this cell line (Girolomoni et al., 1995; Pieri

(a)

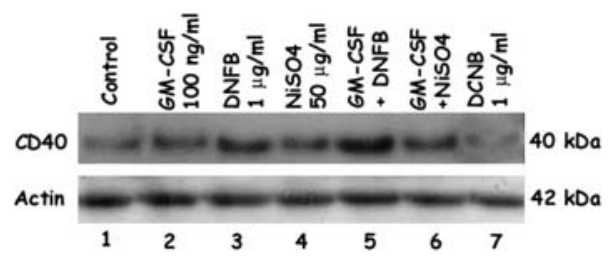

(b)

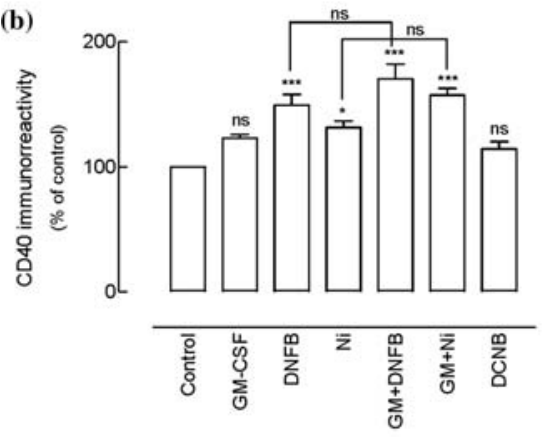

(c)
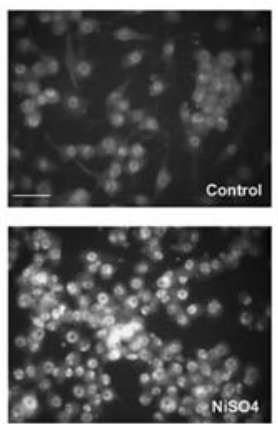

CD40
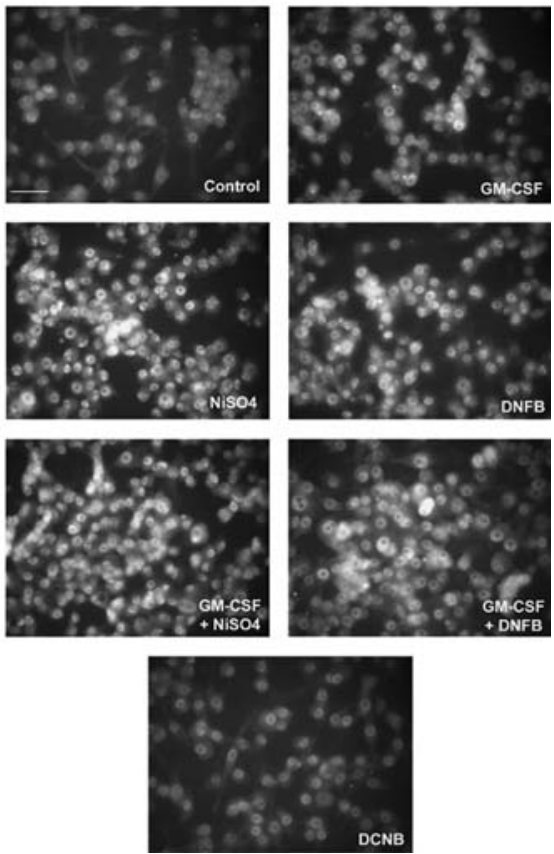

Fig. 1. Effect of GM-CSF on $\mathrm{NiSO}_{4}$ - and DNFB-induced CD40 protein expression. (a) Western blot analysis of CD40 protein. FSDC cells $\left(2 \times 10^{6}\right.$ cells $)$ were incubated in culture medium in the absence (control, lane 1) or in the presence of GM-CSF $\left(100 \mathrm{ng} / \mathrm{ml}\right.$, lane 2), DNFB $(1 \mu \mathrm{g} / \mathrm{ml}$, lane 3$)$ or $\mathrm{NiSO}_{4}$ $(50 \mu \mathrm{g} / \mathrm{ml}$, lane 4). Where indicated, the cells were stimulated with GM-CSF in the presence of DNFB $\left(1 \mu \mathrm{g} / \mathrm{ml}\right.$, lane 5) or $\mathrm{NiSO}_{4}(50 \mu \mathrm{g} / \mathrm{ml}$, lane 6). Total cell extracts were electrophoresed through SDS-PAGE and subjected to western blot analysis using an anti-CD40 antibody, as described in "Materials and Methods". The blot shown is representative of three blots yielding similar results. The blot was digitally generated using a HP ScanJet 5p and processed in the Adobe Photoshop 7.0 program. (b) The bands were quantified with an image analyser. The values are means \pm SEM from three independent experiments, where $* p<0.05, * * p<0.01$ and $* * * p<0.001$, as determined by one-way ANOVA with Bonferroni?s multiple comparison test. (c) Immunofluorescence analysis of CD40 protein. FSDC cells $\left(0.2 \times 10^{6}\right.$ cells $)$ were incubated on a Lab Tek chamber with cover, under the same conditions as described in A. Immunostaining was performed as described in "Materials and Methods". Immunorreactivity means CD40 protein expression ( $\%$ of control). Scale bars $=50 \mu \mathrm{m}$. 
et al., 2001). As shown in Fig. 1a and b, incubation of FSDC cells with GM-CSF, for $48 \mathrm{hr}$, increased the expression of CD40 by $23 \%$, but this effect did not reach statistical significance (Fig. 1a, lane 2). However, when FSDC cells were incubated with $\mathrm{NiSO}_{4}(50 \mu \mathrm{g} / \mathrm{ml})$ or DNFB $(1 \mu \mathrm{g} / \mathrm{ml})$, for $24 \mathrm{hr}$, together with GM-CSF, after a $24 \mathrm{hr}$ pre-incubation with the cytokine, the increase in the expression of CD40 was slightly higher but not statistically different from that observed in the presence of the sensitizers alone (58 and 70\%, respectively) (Fig. 1a, lanes 5 and 6). Interestingly, the small effect of GM-CSF on the expression of CD40 appears to be additive with the response to the sensitizers. When the cells were incubated with the non-sensitizer DCNB the observed effect was not different from the control (Fig. 1a, lane 7).

In Fig. 1c, immunofluorescence microscopy experiments performed under the same experimental conditions confirmed all these results, demonstrating an upregulation of CD40 expression induced by the sensitizers $\mathrm{NiSO}_{4}$ and $\mathrm{DNFB}$, and a slightly higher increase in the expression of the protein in cells pre-incubated with GM-CSF. Immunofluorescence also confirmed that the non-sensitizer DCNB had no significant effect on this model.

\section{Effect of $\mathrm{NiSO}_{4}$, DNFB and DCNB on IL-12R expression in FSDC}

The effect of $\mathrm{NiSO}_{4}, \mathrm{DNFB}$ and DCNB on the expression of IL-12R in FSDC cells is summarized in Fig. 2a and b. In FSDC cells incubated with $\mathrm{NiSO}_{4}(50 \mu \mathrm{g} / \mathrm{ml})$ or with DNFB $(1 \mu \mathrm{g} / \mathrm{ml})$, for $24 \mathrm{hr}$, the expression of IL-12R was increased by 45 and $72 \%$, respectively, when compared with control cells, i.e., cells incubated with culture medium (Fig. 2a, lanes 1, 4 and 5). DCNB had no effect on this model (Fig. 2a, lane 7). In order to determine how FSDC maturation affects the expression of the IL-12R induced by sensitizers, the cells were pre-incubated with GM-CSF (100 ng/ml), for $24 \mathrm{hr}$, before stimulation for an additional $24 \mathrm{hr}$ with $\mathrm{NiSO}_{4}$ or DNFB, together with the cytokine. When the cells were incubated only with GM-CSF, for $48 \mathrm{hr}$, we observed a non-statistically significant increase of IL-12R expression of $23 \%$ (Fig 2a, lane 2). When FSDC cells were incubated with the sensitizers $\mathrm{NiSO}_{4}(50 \mu \mathrm{g} / \mathrm{ml})$ or DNFB $(1 \mu \mathrm{g} / \mathrm{ml})$, for $24 \mathrm{hr}$, together with GM-CSF, after a $24 \mathrm{hr}$ pre-incubation with the cytokine, the increase in IL-12R expression (66 and 90\%, respectively) was higher but not statistically different from that observed in cells stimulated only by the sensitizers (Fig. 2a, lanes 3 and 6). As observed for the expression of CD40, the small effect of GM-CSF on IL-12R expression was additive with the response to the sensitizers. When the cells were incubated with the non-sensitizer DCNB the observed effect was not different from the control (Fig. 2a, lane 7).

In Fig. 2c, immunofluorescence microscopy confirmed all of these results, demonstrating an upregulation of IL-12R expression induced by the sensitizers $\mathrm{NiSO}_{4}$ and DNFB in cells pre-incubated or not with GM-CSF. The immunofluorescence also confirmed that the non-sensitizer DCNB did not affect the expression of the IL-12R.

\section{DISCUSSION}

FSDC is a fetal mouse skin derived dendritic cell line, which represents a model of a skin DC precursor. These cells are sensitive to and require cytokine activation to 
become functionally efficient APCs (Girolomoni et al., 1995). We have previously shown that FSDC are sensitive to the epidermal cytokine GM-CSF (Cruz et al., 2001; Vital et al., 2003), which is involved on DC differentiation and maturation (Kimber et al., 1995; Jonuleit et al., 1996; Banchereau and Steinman, 1998).

In this work, we studied the effect of two strong contact sensitizers, DNFB and $\mathrm{NiSO}_{4}$, on the expression of two membrane-associated receptors, CD40 and IL-12R, in FSDC. The results show that both skin sensitizers upregulated the expression of the two cell surface molecules, CD40 and IL-12R, whereas the non-sensitizer DCNB had no significant effect (Figs. 1 and 2). In another set of experiments we tested the effect of pre-incubating FSDC with GM-CSF, which induces FSDC maturation (Kimber et al., 1995; Jonuleit et al., 1996; Pieri et al., 2001), on the response to the

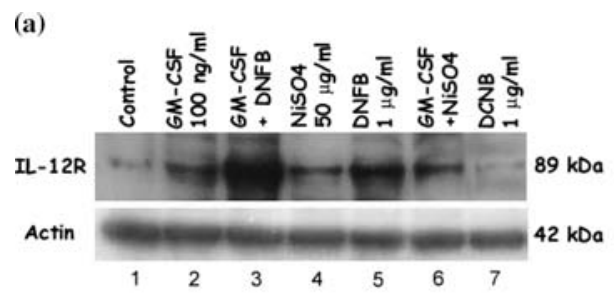

(c) IL-12R

(b)
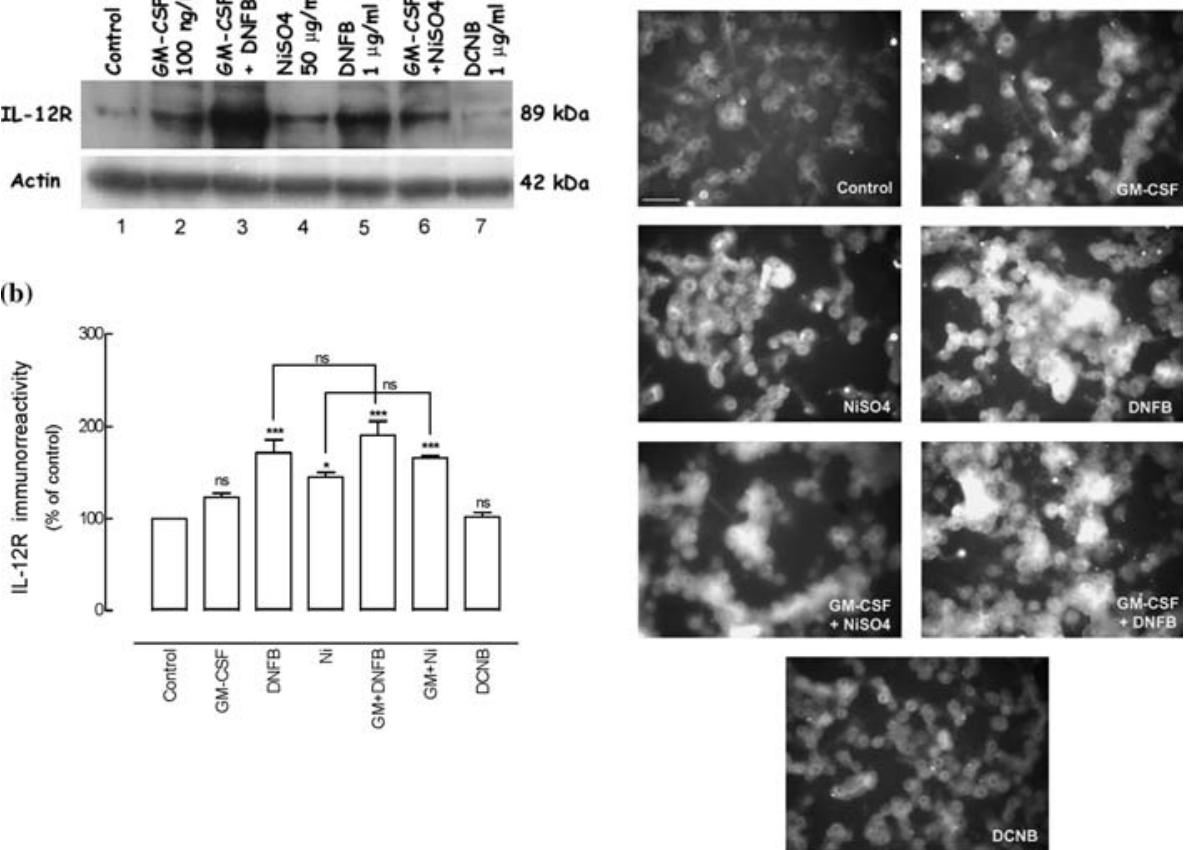

Fig. 2. Effect of GM-CSF on $\mathrm{NiSO}_{4}$ - and DNFB-induced IL-12R expression. (a) Western blot analysis of IL-12R $\beta 1$ protein. FSDC cells $\left(2 \times 10^{6}\right.$ cells) were incubated in the absence (control, lane 1$)$ or in the presence of GM-CSF (100 ng/ml, lane 2), $\mathrm{NiSO}_{4}(50 \mu \mathrm{g} / \mathrm{ml}$, lane 4) or DNFB $(1 \mu \mathrm{g} / \mathrm{ml}$, lane 5). Where indicated, the cells were stimulated with GM-CSF in the presence of DNFB $(1 \mu \mathrm{g} / \mathrm{ml}$, lane 3$)$ or $\mathrm{NiSO}_{4}$ $(50 \mu \mathrm{g} / \mathrm{ml}$, lane 6). Total cell extracts were electrophoresed through SDS-PAGE and subjected to western blot analysis using an anti-IL-12R $\beta 1$ antibody, as described in materials and methods. The blot shown is representative of three blots yielding similar results. The blot was digitally generated using a HP ScanJet $5 \mathrm{p}$ and processed in the Adobe Photoshop 7.0 program. (b) The bands were quantified with an image analyser. The values are means \pm SEM from three independent experiments, where $* p<0.05$, $* * p<0.01$ and $* * * p<0.001$, as determined by one-way ANOVA with Bonferroni's multiple comparison test. (c) Immunofluorescence analysis of IL-12R protein. FSDC cells $\left(0.2 \times 10^{6}\right.$ cells) were incubated on a Lab Tek chamber with cover, under the same conditions as described in A. Immunostaining assay was performed as described in materials and methods. Immunorreactivity means IL-12R protein expression ( $\%$ of control). Scale bars $=50 \mu \mathrm{m}$. 
sensitizers. The results show that GM-CSF alone slightly increased CD40 and IL$12 \mathrm{R}$ expression, and this effect was additive with the result of cell stimulation only with the allergens (Figs. 1 and 2).

The upregulation in the expression of CD40 observed here (Fig. 1) is in agreement with the results obtained in other DCs (Coutant et al., 1999). CD40 is a membrane-associated receptor belonging to the tumor necrosis factor-receptor (TNF-R) family that is expressed broadly, including in DCs (van Kooten and Banchereau, 2000). CD40 interacts with the CD40 ligand (CD40L) on naïve T cells in a process important for initiating primary immune responses (Banchereau et al., 2000). CD40 activation by CD40L is critical for maintaining DC viability, to promote their maturation through the upregulation of costimulatory molecules and to control their migration to the draining lymph nodes (Moodycliffe et al., 2000; Mann et al., 2002). CD40 ligation also activates cytokine gene expression in DCs and promotes IL-6 and IL-12 secretion, which is important in driving T cell development and in the initiation of primary immune responses (Mann et al., 2002; Wesa and Galy, 2002). Therefore, CD40 could be regarded as a surface marker of DC activation. In the present work we also found that DNFB induced a higher increase in CD40 expression than $\mathrm{NiSO}_{4}$ (Fig. 1), which is in agreement with the in vitro and in vivo stronger activity of this skin sensitizer (Yokozeki et al., 1995).

FSDC were cultured with GM-CSF in the absence or in the presence of the contact sensitizers, in order to mimic the in vivo events. During CHS, epidermal keratinocytes provide a wide range of cytokines that influence the differentiation of cells of the dendritic lineage, in particular Langerhans cells. GM-CSF is one of these cytokines, relevant for the maintenance of the differentiated state of LCs within epidermis (Pieri et al., 2001). Also, a variety of environmental stimuli, including epicutaneous contact with the skin sensitizers used in the present work, induce epidermal keratinocytes to release inflammatory and chemotactic cytokines and growth promoting cytokines, namely GM-CSF (Corsini and Galli, 1998). In fact, our results show that GM-CSF alone slightly increased CD40 expression, a marker of DC maturation, which is in agreement with a previous report showing that GMCSF slightly upregulated CD40 expression in purified LCs (Salgado et al., 1999). The slightly higher CD40 upregulation in the presence of GM-CSF together with sensitizers indicate that the effect of these two stimuli was additive. The gene that codes for CD40 contains $\mathrm{NF}-\kappa \mathrm{B}$ binding sites in its enhancer promoter regions (Yoshimura et al., 2001; Nguyen and Benveniste, 2002), and this may constitute the mechanism whereby CD40 protein levels are upregulated by allergens and by this epidermal cytokine. Indeed, GM-CSF, $\mathrm{NiSO}_{4}$ and DNFB activate the NF- $\kappa \mathrm{B}$ transcription factor in FSDC (Cruz et al., 2001; Cruz et al., 2002; Vital et al., 2003). $\mathrm{NiSO}_{4}$ induces the translocation of p65, RelB and cRel from the cytosol to the nucleus, whereas GM-CSF induces the translocation of p50, p52 and RelB proteins (Cruz et al., 2001; Cruz et al., 2002). The differential activation of NF-кB components by GM-CSF and $\mathrm{NiSO}_{4}$ may explain the additive effect of GM-CSF and $\mathrm{NiSO}_{4}$ on CD40 protein levels. In contrast, GM-CSF and DNFB activate the same $\mathrm{NF}-\kappa \mathrm{B}$ elements, suggesting that the regulation of CD40 by the cytokine and the allergen may involve additional signaling events.

The sensitizers DNFB and $\mathrm{NiSO}_{4}$ also increased the expression of IL-12R, as shown in Fig. 2. In addition, GM-CSF upregulated this effect when was tested 
together with the sensitizers. The IL-12R complex is composed of two beta-type cytokine receptor subunits, IL-12R $\beta 1$ and IL-12R $\beta 2$ (Presky et al., 1996; Nagayama et al., 2000) and has been described in dendritic cells, T cells, NK cells and other PBMC (Desai et al., 1992; Chua et al., 1994; Chua et al., 1995; Presky et al., 1996). IL-12R $\beta 1$ mediates the signaling events induced by IL-12 on DCs, which promote their functional activation (Grohmann et al., 1998; Nagayama et al., 2000). However, the effect of skin sensitizers on IL-12R expression had never been addressed before.

Previous reports have shown that contact sensitizers like DNCB, which has a similar sensitizing potential as DNFB, can induce IL-12p40 subunit production by some APCs (Warbrick et al., 1999). Therefore, DC upregulation of IL-12R induced by the sensitizers could be fundamental for the engagement of IL-12 produced by the DC itself or by other cells in the vicinity, thus promoting IL-12 signaling and functional DC activation. Accordingly, studies concerning the regulation of IL-12R have shown that an increase in IL-12 production and release is sufficient to induce expression of the two subunits of IL-12R, beta 1 and beta 2, by an autocrine mechanism in T cells (Rogge et al., 1997; Kim et al., 2001). One of the signaling pathways activated by IL-12 after binding to its receptor involves members of NF$\kappa \mathrm{B}$ in DCs (Grohmann et al., 1998; Yoshimura et al., 2001) and, therefore, it is possible that the expression of IL-12R is dependent on NF- $\kappa B$. Since GM-CSF, $\mathrm{NiSO}_{4}$ and DNFB also activates NF-кB in FSDC (Cruz et al., 2001; Cruz et al., 2002; Vital et al., 2003), this may be the mechanism whereby the cytokine and the sensitizers upregulate IL-12R protein levels in the cells.

IL-12 is a pivotal cytokine during antigen presentation, inducing functional activation of DCs, by the upregulation of the expression of MHC-II molecules (Grohmann U et al., 1998; Kelleher and Knight, 1998; Nagayama et al., 2000) and the secretion of several cytokines, namely GM-CSF, IL- $1 \beta$, IL-6, TNF- $\alpha$, IFN- $\gamma$ and IL-12p40 subunit itself (Grohmann et al., 1998; Kelleher and Knight, 1998; Nagayama et al., 2000). Since haptens induce IL-12 production by antigen presenting cells, namely DCs (Warbrick et al., 1999), the upregulation of IL-12R in FSDC reported here suggests that the sensitizers cause a general upregulation of IL-12 function. This also suggests that IL-12 may play a key role in the response of DCs to the presence of the sensitizers.

In summary, we observed that the two skin contact sensitizers, DNFB and $\mathrm{NiSO}_{4}$, increased FSDC expression of the two membrane-associated receptors, CD40 and IL-12R, whereas the non-sensitizer DCNB had no significant effect as expected. GM-CSF also increased in a small extent the expression of both proteins, and this effect was additive with the effect of the allergens. These results suggest that these skin contact sensitizers induced early specific phenotype changes that may represent an early-activation state of the DCs, which could be responsible for the initiation of the sensitization phase of CHS in vivo. In addition, these results also suggest that the epidermal cytokine GM-CSF is involved on these changes. Moreover, we interestingly observed that the higher expression of CD40 and IL-12R was obtained with the stronger sensitizer DNFB, whereas $\mathrm{NiSO}_{4}$ induced a lower expression of those proteins. Our results suggest that upregulation of CD40 and IL-12R expression could also be a promising readout in prescreening for strong and moderate contact sensitizers and could help to develop an in vitro assay to reduce the 
number of experimental animals used for ascertaining the sensitizing potential of environmental chemicals.

\section{ACKNOWLEDGMENTS}

This work was supported by the Portuguese Foundation for Science and Technology, project number 36373/99.

\section{REFERENCES}

1. Aiba, S., Manome, H., Yoshino, Y., and Tagami, H. (2000) In vitro treatment of human transforming growth factor-betal-treated monocyte-derived dendritic cells with haptens can induce the phenotypic and functional changes similar to epidermal Langerhans cells in the initiation phase of allergic contact sensitivity reaction. Immunology. 101:68-75.

2. Banchereau, J, Briere, F, Caux, C, Davoust, J, Lebecque, S, Liu, Y. J, Pulendran, B, and Palucka, K. (2000) Immunobiology of dendritic cells. Annu. Rev. Immunol. 18:767-811.

3. Banchereau, J and Steinman, R. M. (1998) Dendritic cells and the control of immunity. Nature. 392:245-252.

4. Becker, D, Kolde, G, Reske, K, and Knop, J. (1994) An in vitro test for endocytotic activation of murine epidermal Langerhans cells under the influence of contact allergens. J. Immunol. Meth. 169:195-204.

5. Chua, A. O, Chizzonite, R, Desai, B. B, Truitt, T. P, Nunes, P, Minetti, L. J, Warrier, R. R, Presky, D. H, Levine, J. F, and Gately, M. K. (1994) Expression cloning of a human IL-12 receptor component. A new member of the cytokine receptor superfamily with strong homology to gp 130 . J. Immunol. 153:128-136.

6. Chua, AO, Wilkinson, V. L, Presky, D. H, and Gubler, U. (1995) Cloning and characterization of a mouse IL-12 receptor-beta component. J. Immunol. 155:4286-4294.

7. Corsini, E and Galli, C. L. (1998) Cytokines and irritant contact dermatitis. Toxicol. Lett. 102-103:277-282.

8. Coutant, K. D, Fraissinette, A Bde, Cordier, A, and Ulrich, P. (1999) Modulation of the activity of human monocyte-derived dendritic cells by chemical haptensa metal allergen, and a staphylococcal superantigen. Toxicol. Sci. 52:189-198.

9. Cruz, M. T, Duarte, C. B, Goncalo, M, Figueiredo, A, Carvalho, A. P, and Lopes, M. C. (2001) Granulocyte-macrophage colony-stimulating factor activates the transcription of nuclear factor kappa $\mathrm{B}$ and induces the expression of nitric oxide synthase in a skin dendritic cell line. Immunol. Cell. Biol. 79:590-596.

10. Cruz, M. T, Duarte, C. B, Goncalo, M, Figueiredo, A, Carvalho, A. P, and Lopes, M. C. (2002) Differential activation of nuclear factor kappa B subunits in a skin dendritic cell line in response to the strong sensitizer 24-dinitrofluorobenzene.Arch. Dermatol. Res. 294:419-425.

11. Smedt, A. CDe, Heuvel, R. LVan Den, Zwi Berneman, N, and Schoeters, G. E. (2001) Modulation of phenotypecytokine production and stimulatory function of CD34+-derived DC by $\mathrm{NiCl}(2)$ and SDS. Toxicol. In Vitro. 15:319-325.

12. Desai, B. B, Quinn, P. M, Wolitzky, A. G, Mongini, P. K, Chizzonite, R, and Gately, M. K. (1992) IL-12 receptor. II. Distribution and regulation of receptor expression. J. Immunol. 148:3125-3132.

13. Enk, A. H (1997) Allergic contact dermatitis: understanding the immune response and potential for targeted therapy using cytokines. Mol. Med. Today. 3:423-428.

14. Girolomoni, G, Lutz, M. B, Pastore, S, Assmann, C. U, Cavani, A, and Ricciardi-Castagnoli, P. (1995) Establishment of a cell line with features of early dendritic cell precursors from fetal mouse skin. Eur. J. Immunol. 25:2163-2169.

15. Grohmann, U, Belladonna, M. L, Bianchi, R, Orabona, C, Ayroldi, E, Fioretti, M. C, and Puccetti, P. (1998) IL-12 acts directly on DC to promote nuclear localization of NF-kappaB and primes DC for IL-12 production. Immunity. 9:315-323. 
16. Herouet, C, Cottin, M, LeClaire, J, Enk, A, and Rousset, F. (2000) Contact sensitizers specifically increase MHC class II expression on murine immature dendritic cells. In Vitro Mol. Toxicol. 13:113-123.

17. Jonuleit, H, Knop, J, and Enk, A. H. (1996) Cytokines and their effects on maturation differentiation and migration of dendritic cells. Arch. Dermatol. Res. 289:1-8.

18. Kelleher, P and Knight, S. C. (1998) IL-12 increases CD80 expression and the stimulatory capacity of bone marrow-derived dendritic cells. Int. Immunol. 10:749-755.

19. Kim, J, Uyemura, K, Dyke, M. KVan, Legaspi, A. J, Rea, T. H, Shuai, K, and Modlin, R. L. (2001) A role for IL-12 receptor expression and signal transduction in host defense in leprosy. J. Immunol. 167:779-786.

20. Kimber, I, Holliday, M. R, and Dearman, R. J. (1995) Cytokine regulation of chemical sensitization. Toxicol. Lett. 82-83:491-496.

21. Lipscomb, M. F and Masten, B. J. (2002) Dendritic cells: immune regulators in health and disease. Physiol. Rev. 82:97-130.

22. Mann, J, Oakley, F, Johnson, P. W, and Mann, D. A. (2002) CD40 induces interleukin-6 gene transcription in dendritic cells: regulation by TRAF2, AP-1, NF-kappa B, AND CBF1. J. Biol. Chem. 277:17125-17138.

23. Moodycliffe, A. M, Shreedhar, V, Ullrich, S. E, Walterscheid, J, Bucana, C, Kripke, M. L, and FloresRomo, L. (2000) CD40-CD40 ligand interactions in vivo regulate migration of antigen-bearing dendritic cells from the skin to draining lymph nodes. J. Exp. Med. 191:2011-2020.

24. Mosmann, T (1983) Rapid colorimetric assay for cellular growth and survival: application to proliferation and cytotoxicity assays. J. Immunol. Meth. 65:55-63.

25. Nagayama, H, Sato, K, Kawasaki, H, Enomoto, M, Morimoto, C, Tadokoro, K, Juji, T, Asano, S, and Takahashi, T. A. (2000) IL-12 responsiveness and expression of IL-12 receptor in human peripheral blood monocyte-derived dendritic cells. J. Immunol. 165:59-66.

26. Nguyen, V. T and Benveniste, E. N. (2002) Critical role of tumor necrosis factor-alpha and NFkappa B in interferon-gamma -induced CD40 expression in microglia/macrophages. J. Biol. Chem. 277:13796-13803.

27. Pichowski, J. S, Cumberbatch, M, Dearman, Basketter, D. A, and Kimber, I. (2000) Investigation of induced changes in interleukin lbeta mRNA expression by cultured human dendritic cells as an in vitro approach to skin sensitization testing. Toxicol. In Vitro. 14:351-360.

28. Pieri, L, Domenici, L, and Romagnoli, P. (2001) Langerhans cells differentiation: a three-act play. Ital. J. Anat. Embryol. 106:47-69.

29. Presky, D. H, Yang, H, Minetti, L. J, Chua, A. O, Nabavi, N, Wu, C. Y, Gately, M. K, and Gubler, U. (1996) A functional interleukin 12 receptor complex is composed of two beta-type cytokine receptor subunits. Proc. Natl. Acad. Sci. USA. 93:14002-14007.

30. Ratzinger, G, Stoitzner, P, Ebner, S, Lutz, M. B, Layton, G. T, Rainer, C, Senior, R. M, Shipley, J. M, Fritsch, P, Schuler, G, and Romani, N. (2002) Matrix metalloproteinases 9 and 2 are necessary for the migration of Langerhans cells and dermal dendritic cells from human and murine skin. J. Immunol. 168:4361-4371.

31. Rogge, L, Barberis-Maino, L, Biffi, M, Passini, N, Presky, D. H, Gubler, U, and Sinigaglia, F. (1997) Selective expression of an interleukin-12 receptor component by human T helper 1 cells. J. Exp. Med. 185:825-831.

32. Salgado, C. G, Nakamura, K, Sugaya, M, Tada, Y, Asahina, A, Fukuda, S, Koyama, Y, Irie, S, and Tamaki, K. (1999) Differential effects of cytokines and immunosuppressive drugs on CD40, B7-1, and B7-2 expression on purified epidermal Langerhans cells1. J. Invest. Dermatol. 113:1021-1027.

33. Satthaporn, S and Eremin, O. (2001) Dendritic cells (I): Biological functions. J. R. Coll. Surg. Edinb. 46:9-19.

34. Tuschl, H and Kovac, R. (2001) Langerhans cells and immature dendritic cells as model systems for screening of skin sensitizers. Toxicol. In Vitro. 15:327-331.

35. Tuschl, H, Kovac, R, and Weber, E. (2000) The expression of surface markers on dendritic cells as indicators for the sensitizing potential of chemicals. Toxicol. In Vitro. 14:541-549.

36. Kooten, CVan and Banchereau, J. (2000) CD40-CD40 ligand. J. Leukoc. Biol. 67:2-17.

37. Vital, A. L, Goncalo, M, Cruz, M. T, Figueiredo, A, Duarte, C. B, and Celeste Lopes, M. (2003) Dexamethasone prevents granulocyte-macrophage colony-stimulating factor-induced nuclear factorkappaB activationinducible nitric oxide synthase expression and nitric oxide production in a skin dendritic cell line. Mediators Inflamm. 12:71-78. 
38. Warbrick, E. V, Dearman, R. J, Basketter, D. A, and Kimber, I. (1999) Analysis of interleukin 12 protein production and mRNA expression in mice exposed topically to chemical allergens. Toxicology. 132:57-66.

39. Watanabe, H, Unger, M, Tuvel, B, Wang, B, and Sauder, D. N. (2002) Contact hypersensitivity: the mechanism of immune responses and $\mathrm{T}$ cell balance. J. Interferon Cytokine Res. 22:407-412.

40. Wesa, A and Galy, A. (2002) Increased production of pro-inflammatory cytokines and enhanced T cell responses after activation of human dendritic cells with IL-1 and CD40 ligand. BMC Immunol. 3:14.

41. Yokozeki, H, Katayama, I, and Nishioka, K. (1995) Experimental study for the development of an in vitro test for contact allergens. 1. Primary activation of hapten-specific T cells by hapten-conjugated epidermal cells. Int. Arch. Allergy Immunol. 106:394-400.

42. Yoshimura, S, Bondeson, J, Foxwell, B. M, Brennan, F. M, and Feldmann, M. (2001) Effective antigen presentation by dendritic cells is NF-kappaB dependent: coordinate regulation of MHC, co-stimulatory molecules and cytokines. Int. Immunol. 13:675-83. 